\title{
ODMEVI ADAMIČEVIH DEL V AMERIŠKEM IN SLOVENSKEM ČASOPISJU MED LETOMA 1931 IN 1934
}

\author{
Milan MRĐENOVIĆ
}

COBISS 1.02

\section{IZVLEČEK}

\section{Odmevi Adamičevih del v ameriškem in slovenskem časopisju med letoma} 1931 in 1934

Članek prikazuje odzive ameriških in slovenskih časnikov, tednikov, mesečnikov in drugih poročil na Adamičeve prve tri knjige, ki so v ZDA izšle med letoma 1931 in 1934. Avtor v članku obravnava tako pozitivne kot negativne kritike njegovih del, pri čemer si pomaga z Adamičevimi knjigami, s spomini, korespondenco in strokovnimi članki, ki so se ukvarjali z njegovima pisanjem in delovanjem. Primerja odzive bralcev in jih sooča z relevantnimi spoznanji in zgodovinskimi dejstvi ter dostopnim arhivskim gradivom. Članek prikaže, kako se je Adamič na začetku literarnega razvoja počasi spreminjal v poznavalca priseljenskih tematik.

KLJUČNE BESEDE: Louis Adamič, priseljenske teme, recenzije, časopisi, izseljenstvo

\section{ABSTRACT}

\section{Reactions to Adamic's Work in the American and Slovenian Press between 1931 and 1934}

The article presents the reactions of American and Slovenian daily, weekly and monthly periodicals to Adamic's first three books, published in the USA between 1931 and 1934. Both positive and negative responses are discussed. All relevant sources are employed: Adamic's books, memoires, and correspondence, and academic articles on Adamic's writing. The author compares readers' responses to relevant findings and historical facts as well as archival material. The article presents Adamic's gradual progress from his initial writings to his later years when he became a well-known authority on immigrant issues.

KEY WORDS: Louis Adamic, immigration topics, reviews, press, emigration

Univ. dipl. zgodovinar, doktorski študent Ameriških študij na Oddelku za zgodovino Filozofske fakultete Univerze v Ljubljani, Aškerčeva 2, SI-1000 Ljubljana; milan.mr85@gmail.com 


\section{UVOD}

O Louisu Adamiču in njegovem delu je bilo že veliko napisanega, tudi o obdobju, ki ga obravnavam v pričujočem članku. Med glavne »adamičeslovce«, ki so raziskovali njegovo delovanje pred drugo svetovno vojno, prištevamo profesorja Herrya Christiana, Jernejo Petrič in Dana Shiffmana. Obrobno se je s tem obdobjem ukvarjal tudi Ivan Čizmić. Vsak, ki se ukvarja z Adamičem, se najprej seznani z delom Henrya Christiana in njegovo bibliografijo o Adamičevih delih A Checklist (Christian 1971a: 1). Dan Shiffman, sicer novejši avtor, je posebno pozornost posvetil njegovemu multikulturalizmu, morda pa $v$ svojem delu pozablja na historizem, to je, da moramo vsako dejanje in delo vsakega avtorja presojati z vidika časa, $v$ katerem je živel. Prav tako Shiffmanovo delo ni kronološko urejeno. Povsem drugače je Adamičevo obdobje, ko je Adamiča obravnaval z vidika njegovega obiska v Jugoslaviji med obema vojnama in pisanja v tem obdobju, prikazal hrvaški zgodovinar Ivan Čizmić. Tudi Henry Christian je Adamičevo interpretacijo Kardeljevega dela Boj obravnaval z vsemi pikantnimi podrobnostmi mučenja političnih jetnikov v Kraljevini Jugoslaviji. Jerneja Petrič pa se je ukvarjala z Adamičevo literarno zapuščino.

Pričujoči prispevek k obravnavi Adamičevega dela in še zlasti odmevov nanj je omogočila najnovejša tehnologija spletnega brskanja. V digitalni knjižnici Slovenije so skenirani skoraj vsi časniki in revije iz tega obdobja. Tako sem lahko identificiral številne komentarje na Adamičeva dela, ki jih vseh skupaj do sedaj iz povsem objektivnih razlogov ni bilo mogoče najti. Moj prispevek Adamiču posveča pozornost v najbolj ključnem obdobju, ko je njegova prepoznavnost najbolj rasla, prav takrat se je uveljavil kot literarni novinar, pisatelj in komentator vseh takratnih pomembnih dogodkov in vprašanj.

\section{ODMEVI NA KNJIGO »DINAMIT«}

Louis Adamič je bil, tako kot pravi Vladimir Dedijer v intervjuju z Janjo Žitnik, človek $v$ iskanju resnice. Dodal bi še, da se je Adamičeva osebnost izražala v njegovi neodvisnosti, ki jo je s kritično distanco ohranjal do vseh akterjev in dogodkov svojega časa (Žitnik 1995a: 25). Že na začetku svoje ustvarjalne poti je bil prepoznan kot izseljenski pisatelj, ki piše o resničnih dogodkih in jih po svoje interpretira, kar je pokazal v prvih dveh delih, ki so požele velik uspeh tako v ZDA kot v Kraljevini Jugoslaviji (Dinamit in Smeh $v$ džungli). Pisal je o delavskem gibanju v ZDA in izseljencih, pri čemer si je podrobnosti pogosto izmišljal. $\vee$ svojem prvem delu Dinamit, $v$ katerem je opisoval dogodke iz življenja delavskega razreda in se postavljal na njihovo stran, je odpiral zahtevna socialna vprašanja. Knjiga opisuje zgodovino razrednega nasilja v ZDA ter možnost nadaljnjega razvoja s pomočjo organiziranih sindikatov (Žitnik 1995b: 11; Adamič 1983: 344, 363). 
Zanimivo je, da je prvo recenzentsko mnenje o Dinamitu izšlo v katoliškem literarnem mesečniku Dom in svet, ki je ob tej priložnosti zapisal, da je "Louis Adamič, po rodu Slovenec, eden izmed tistih redkih slovenskih izseljencev, ki so si samostojno utrli pot $v$ tujo književnost in tam svojo izredno nadarjenost pokazali in dokazali (sic)«. $\vee$ recenziji omenjajo, da je krvavo nasilje in brezobzirno zatiranje delavcev obstajalo še preden je ruska revolucija leta 1917 pretresla temelje zahodnega sveta. Recenzent Ludvik Klakočer, takrat v Sloveniji priznani prevajalec, je ugotovil, da so si radikalne ideje svojo pot $v$ ZDA utrle zaradi nerešenih notranjih socialnih razmer, ki so vladale med delavci še pred izbruhom oktobrske revolucije. Socialna kriza se je najbolj odražala med priseljenci, ki so predstavljali največji delež med nekvalificiranimi delavci v ZDA. Recenzija se konča s čestitko avtorju, ki je uspel kljub dejstvu, da je bil priseljenec. ${ }^{2}$

V uvodnem poglavju Dinamita je Adamič zapisal, kako je naivnost mnoge priseljence pripeljala v situacijo, da so jih, čeprav so se borili za svoje pravice, zmerjali kot "govno« in »zavrženo sodrgo«. Tako so povprečni Američani dojemali delavske stavke in proteste. Adamič v knjigi navaja, da so takrat manjkali učinkoviti sindikati, ki bi znali izraženi gnev predstaviti na dostojen način (Adamič 1983: 276-277). Adamič v Dinamitu prevzame vlogo zaščitnika delavcev, predvsem priseljenih »ekonomskih migrantov«, ki so veljali za »nekvalificirane delavce«. V liberalnem časniku Jutro je Mile Klopčič, znani slovenski pesnik in prevajalec, navajal, da je Dinamit objektivno delo, v katerem se avtor že v uvodnem delu distancira od radikalizma in se predstavi kot opazovalec dogajanja, ki le simpatizira $z$ delavci. »Nisem aktiven radikalec niti član kake delavske unije, simpatiziram pa $z$ delavci: nimam tudi navade, da bi izgovarjal besedo «kapitalizem s s sikanjem «³ (Adamic 1931: 1).

Po izidu Dinamita so mu čestitali priznani ameriški literati, kot so Upton Sinclair, Sinclair Lewis in Mary Austin. Vrstila so se številna javna priznanja. Napovedovali so prevode v nemški, ruski, češki, japonski in francoski jezik. Napovedan je bil tudi prevod v hrvaški jezik. ${ }^{4} \mathrm{~V}$ liberalnem Mariborskem Večerniku Jutra so avgusta 1932 napisali recenzijo slovenskega prevoda Adamičevih kratkih zgodb, objavljenih v Krizi $\checkmark$ Ameriki, ki jih je prevedel Anton Debeljak. Knjižica je še istega leta izšla v založbi Tiskovne zadruge. V kratkem sestavku so omenili recenzijo Dinamita, kjer so slovenske razmere predstavili kot idilične $v$ primerjavi z Ameriko, ki so jo mnogi še videli kot »obljubljeno deželo«. Čeprav slovenski prevod Dinamita še dolgo ni izšel, so ga v objavljenih ocenah poveličevali do najvišje možne mere. ${ }^{5}$ V Hitlerjevi Nemčiji je bila knjiga celo prepovedana. ${ }^{6}$ Nasprotno pa je bila na ameriških univerzah učbenik študentov družboslovja. Dan Shiffman je v svoji knjigi Korenine multikulturalizma

1 Klakočer, Ludvik, »Dynamite«, Dom in svet 44/7, 8, 9, 1931: 410.

2 Prav tam: 413.

3 Klopčič, Mile, »Veliko književno delo ameriškega Slovenca«, Jutro, 11. april 1931: 6.

4 »Slovenci v tujini«, llustracija 3/9, 1931: 323.

5 »Razkrinkana pravljica o obljubljeni Ameriki«, Mariborski Večernik Jutra, 13. avgust 1932: 5.

6 Arhiv Slovenije (SI AS) 1557, Louis Adamič - kratek opis njegove literarne kariere: 4. 
poudaril, da je bila knjiga leta 1936 obvezno učno gradivo na približno osemdesetih ameriških kolidžih, postala je tudi pomembno referenčno delo vseh glavnih časopisnih hiš v ZDA (Shiffman 2005: 90).

Zaradi nemarksističnega pisanja so Adamiča napadali tako v knjigi obsojani komunisti kot anarhisti. Ker je pisal o odklonih radikalnih skupin in gibanj $v$ ameriški družbi, je bil označen za »socialnega fašista« (Petrič 1981: 155). Mnoge založbe so na začetku odklanjale, da bi knjigo založile, ker so se bale morebitnih tožb, Adamič je namreč odkrito pisal o politikih, sindikalistih in drugih s kriminalnim podzemljem povezanih osebah. Založnik Viking Press je od njega zahteval, da mora pred izidom v knjižni obliki upoštevati nekatere njihove opombe (Christian 1981b: 119). Številne politične kritike ga pri njegovem delu niso ustavile, kvečjemu so ga spodbudile, da je še okrepil svoj literarni aktivizem in s pisanjem ozaveščal, izobraževal in prikazoval resnico, kot jo je videl, razumel in spoznaval v času, ko je bil tudi sam fizični delavec: »Mislim, da je prihodnost v izobraževanju, ne pa v fašistični ali komunistični revoluciji. To drži vsaj za Ameriko, « je pisal v enem od svojih pisem prijatelju v ZDA (prav tam: 265). Nasilna dejanja so dejanja »skrajnega obupa«, v katerem so se delavci znašli zaradi krivičnih delovnih razmer in neučinkovitih sindikatov (Adamič 1983: 157).

\section{ODMEVI NA KNJIGO »SMEH V DŽUNGLI»}

Leta 1932 je izšla njegova druga knjiga Smeh v džungli, ki je hkrati tudi avtobiografija, v katero je dodal precej svojih izmišljenih zgodb. V časniku Slovenec so ob tem zapisali, da je zaradi omenjene knjige dobil prestižno nagrado, Guggenheimovo štipendijo, ki so jo prejemali le najboljši ameriški pisatelji in literarni ustvarjalci. ${ }^{7}$ Tako so ga postavili ob bok sodobnim literarnim ustvarjalcem in pisateljem v ZDA. S štipendijo, ki je znašala 2.500 dolarjev, $^{8}$ se je lahko maja 1932 odpravil na desetmesečno potovanje po Evropi. Večino časa je prebil v Jugoslaviji in tako na novo odkril svojo domovino in jo pozneje tudi opisal (Čizmić 1981: 314).

V recenziji Smeha v džungli so v izseljenski Prosveti zapisali, da je Adamič prišel v ZDA, da bi jo dobro spoznal in opisal. ${ }^{9}$ Morda je najbolj zanimivo mnenje o knjigi napisal delavski aktivist in novinar Benjamin Stolberg, znani kolumnist New York Timesa in New York Herald Tribuna, ko je zapisal, da je Adamič »ponovno odkril Ameriko«, kjer se je opogumil in dvignil nad zgodovinopisje ter končno začel pisati leposlovna dela. S knjigo je avtor pokazal talent za pisanje zgodb, ki pritegnejo pozornost slehernega bralca. Adamič tako ni bil več zgolj avtobiograf in tolmač preteklosti, temveč tudi dober pripovednik..$^{0}$ Tako so v New York Timesu Adamičevo knjigo predstavili kot zanimivo branje, ki opisuje kaos in džunglo v Ameriki in kliče $\mathrm{k}$ aktivnemu smislu

7 »Alojzij Adamič v Sloveniji«, Slovenec,14. maj 1932: 3.

8 SI AS 1557, Louis Adamič - kratek opis njegove literarne kariere: 5.

9 »Nova knjiga Louisa Adamiča«, Prosveta, 23. maj 1932: 3.

10

Prav tam. 
za humor. Prispodoba Amerike kot džungle, ki jo je povzel po Uptonu Sinclairu, in njegov smeh, s katerim je ovekovečil svoje upanje ter dobro voljo, so ameriški kritiki zelo dobro sprejeli"11 (Adamic 1938: 125).

Tudi v slovenskem literarnem prostoru se je takrat o drugi Adamičevi knjigi na veliko pisalo in razglabljalo. $V$ recenziji, objavljeni v katoliškem mesečniku Dom in svet, je Klakočer poudaril, da je Adamičeva knjiga biografija, v kateri avtor iz lastnih težkih preteklih izkušenj opisuje splošne materialne in širše družbene razmere v ZDA. ZDA prikaže kot džunglo, torej deželo, ki lahko hitro pogoltne vsakega razočaranega človeka in ga, ko postane neuporaben, izvrže. V kolikšni meri so bile ZDA še tista »obljubljena dežela«, kjer revni uspevajo in bogatijo s poštenim delom? Klakočer povzema nemškega grofa in filozofa Hermanna Keyserlinga, sicer znanega nemškega kritika militarizma in nacističnega režima, ki je napisal, da celotni nemški »razred intelektualcev« ne zna povedati kaj dosti o Ameriki, saj do nje ne gojijo posebnih simpatij. Tukaj Klakočer pristavi, da je treba Ameriko osebno spoznati.

Najboljša referenca za to je bil prav Adamič, priseljenec slovenskega rodu, ki je tam živeli in uspel, knjiga je imela prav zato posebno veljavo med slovenskimi bralci. Njegovo sporočilo je bilo naslednje: $V$ Ameriki lahko uspejo samo tisti, ki znajo ohraniti smisel za humor. V knjigi opisuje številne primere oseb, ki jih je srečeval in se z njimi spoznal. Vsi so bili priseljenci ali potomci priseljencev s svojimi osebnimi pričakovanji in prepričanji. Mnoge usode so se slabo končale. Tudi materinstvo naj bi se $v$ Ameriki razvodenelo in izgubilo svoj pomen. Poudaril je primer ženske, ki je imela štiri može, trije so umrli, četrti je bil na koncu življenjske poti. To je bila žena, ki je rodila še sedem otrok! Vsi so umrli, razen enega, ki se je izgubil nekje v ameriški džungli. Kaj je potem smisel življenja v Ameriki? Kakšno vlogo igrajo matere $v$ ameriški družbi? Kaj je tej ženski Amerika dala v zameno, da bi bila srečna, ker je izpolnila svoje materinsko poslanstvo? »Mi smo prišli iz stare domovine pomagat Ameriki, da postane velika in grozna, « je odgovarjala ženska Adamiču. $V$ tem delu avtor prikaže, da so bili priseljenci za Ameriko navadno gnojilo, ki jim je namenjeno, da delajo do onemoglosti. Kadar jih potrebujejo za gradnjo nebotičnikov, mostov in železnic, so koristni in dobrodošli. Zdaj, ko je država v krizi, pa so postali nepotrebni in vsem nadležni. ${ }^{12}$ (Adamič 1981: 248)

V svojem dnevniku je Adamič zapisal, da je Amerika čuden kraj, ki ga ne moreš ne preveč ljubiti ne preveč sovražiti. To je kraj nasprotij in protislovij. Nemogoče je Ameriko razumeti, zato se je, čeprav je včasih težko, najbolje smejati. Amerike ne smeš jemati preveč resno, sicer boš razočaran in potrt. Na koncu je celo pristavil, da je vsak poskus, da bi Ameriko spremenili ali vplivali nanjo, jalovo početje. (Klemenčič 1981: 1054)

11 »Findes United States Much Like a Jungle«, New York Times, 28. marec 1932: 19.

12 Klakočer, Ludvik, »Laughing in The Jungle: The Autobiography of An Immigrant in Amerika«, Dom in svet 45, 1932: 329-330. 
Drugo recenzijo je za Dom in svet leta 1933 napisal Jakob Šilc, prav tako dober poznavalec slovenske literarne in umetnostne zgodovine. Napisal je, da knjiga omogoča nov vpogled $v$ neznani svet, kot ga je doživel priseljenec slovenskega rodu. "Smeh je osvobajajoč pogled $v$ življenje in humor je znamenje duševne prostosti, obvladovanje sveta.« Vendar je smeha in smisla za humor v sodobni Ameriki zaradi gospodarske recesije čedalje manj. Smeh postaja znamenje individualizma, ki teži k ohranjanju samega sebe. »Ameriški bog uspeha ukazuje ritem varljivega upanja, v katerem ljudje pozabijo človeške vrednote in skrivnosti sreče.« Zaradi tega so se izgubljali človeške kvalitete, razum in poštenost ljudi. Celo fraza »dežela svobodnih" je izgubljala svojo vrednost. Avtor v priseljencih odkriva novo moč, ki bo do temeljev prenovila Ameriko. ${ }^{13}$

Daleč najbolj zanimivo recenzijo Smeha $v$ džungli je objavil literarni mesečnik Ljubljanski zvon. Napisala jo je Olga Grahor, priznana slovenska anglistka in prevajalka. Grahorjeva pravi, da je Adamič začel pisati kot zgodovinar in poročevalec o ameriških socialnih razmerah, s svojo avtobiografijo pa je, čeprav je knjiga še vedno ohranjala značilnosti reportaže in objektivnega poročanja o pomembnih dogodkih, zakorakal v svet leposlovja. Po njenem mnenju je avtor razmere dokaj objektivno razlagal. Prav tako ocenjuje, da Adamiča »ne moremo šteti za Slovenca, vsaj po načinu razmišljanja ne, saj je po čustvovanju Američan«. Na staro domovino ga vežejo spomini iz otroštva in ljubezen do sorodnikov. Grahorjeva pravi, da je primerjava Adamiča s slovenskimi pisatelji neumestna. Čeprav je Adamič pozneje zapisal, da se počuti kot »slovenski Američan«, bi po mnenju Grahorjeve moral »slovenski pisatelj« živeti in se razvijati v rojstni domovini, ne pa v Ameriki. Adamič je sicer odraščal in se razvijal v drugi deželi, ki ni bila primerljiva s Slovenijo, zato ni mogel biti vzor slovenskim pisateljem ali obratno. Tudi očitek glede pomanjkanja nacionalne zavesti je bil pri Adamiču nepomemben. Adamič je šel svojo pot in se na njej kulturno odtujil slovenskim domačim problemom. Njegovo delo bi morali sprejeti »kakršno pač je«; za nas je zanimivo in pomembno, je zapisala Groharjeva, ker avtor po rodu ni Američan, temveč Slovenec, ki je velik del svojega pisanja posvečal problemom izseljenstva in ga hkrati objektivno opisoval.

Adamič je za slovenskega bralca pomemben tudi zato, ker takšnega dela ne bi mogel napisati noben $v$ Ameriki rojeni pisatelj. Politično naj bi slovenski priseljenci v ZDA živeli dokaj složno, torej brez posebnega zanimanja za ameriško politiko in politično udejstvovanje. Trditev seveda ni točna, saj so se nekateri slovenski priseljenci in njihovi potomci aktivno ukvarjali s politiko ter $v$ njej tudi uspeli, kot npr. Frank Lausche (Klemenčič 2011: 735-763). Najbolj se je politična aktivnost izseljencev v zvezi s Slovenijo povečala ob političnih krizah v Evropi (prva in druga svetovna vojna ter osamosvajanje), ki so sprožala vprašanje nacionalne identitete (prav tam: 53). Grahorjeva je na koncu še dodala, da so se ameriški Slovenci, ki so se ukvarjali s

13 Šilc, Jakob, »Smeh v džungli«, Dom in svet 5, 1933: 268-269. 
politiko, vedno delili na »verne in neverne (klerikalce in socialiste)«, tako da so bile njihove delitve podobne kot v Sloveniji. ${ }^{14}$

Po mnenju Grahorjeve je v pravi džungli tudi precej rodovitne prsti. Iz nje sicer rastejo strupene rastline in drug plevel, so pa v tej goščavi tudi užitni plodovi. Svojo recenzijo konča z besedami, da v džungli uspejo samo mlajši, ki edini premorejo dovolj moči, energije in volje do uspeha. $V$ tem se je Adamič razlikoval od predhodnih avtorjev, saj se je prebil z dna družbe in zaslovel kot pisatelj. Uspel je, ker se ni pustil uporabiti za »gnojilo«, niti ni poskušal v džungli pognati svojih korenin. Raje je »ostal nad njo, da jo opazuje, da se ji smeje in premišljuje o njej. V vsem tem kaosu je vendar videl možnost lepe prihodnosti.« Knjiga je po mnenju Ljubljanskega zvona napisana pošteno in zabavno. ${ }^{15}$

Jeseni 1932 je v Ljubljanskem zvonu izšel članek o Adamičevem delu in njegovem »slovenstvu«. Napisal ga je Oton Župančič, slovenski pesnik, ki je želel spodbuditi Adamičevo ustvarjanje v Ameriki. Zapisal je, da je Adamič optimistično zazrt v prihodnost, pri tem pa ga spremlja njegov »vedri in zdravi smeh«, ki ga je podedoval po slovenski materi. Nato se je obregnil ob »budne stražarje«, ki naj bi v rodni deželi bdeli nad razvojem slovenstva v literaturi. Dodal je še, da je bil Adamič uspešen zato, ker je zapustil Slovenijo oziroma domače kraje ter začel delovati v tujini, kjer ni bilo »budnih stražarjev«, ki bi nadzirali njegovo ustvarjanje in pisanje. Prav zato je lahko postal uspešen in prepoznaven pisatelj. Tovrstno omejevanje naj bi slovensko literaturo precej omrtvičilo. Župančič v medvojnem obdobju v Sloveniji omenja pomankanje optimizma, smeha in drugačne miselnosti. Slovenstvu, ki se je omejevalo na Slovenijo, naj bi manjkal kozmopolitizem. ${ }^{16}$ (Žitnik 2002: 121-130)

Kritiki seveda niso molčali. Obregnili so se ob Župančičev članek, ki je preveč polemiziral o slovenskem narodnem vprašanju ter postavljal Adamiča za nekakšnega zglednega pisatelja, ki je svoje poslanstvo bolje opravljal v tujini, kot če bi ostal doma. Adamič se v tej fazi še ni imel za »slovenskega Američana«, poleg tega je pisal samo $v$ angleščini. Po mnenju Župančičevih kritikov je bila uporaba slovenščine ključna značilnost »slovenstva«. To je sicer v prej omenjeni recenziji ugotovila že Olga Grahor. V Ljubljanskem zvonu je zaradi cenzure, ki je preprečila nadaljnje objavljanje komentarjev oziroma kritike na račun Župančičevega članka, nastala kriza, ki se je končala $z$ razkolom in odhodom pomembnih članov oziroma sodelavcev časopisa; ti so pozneje ustanovili novega z nazivom Sodobnost. (Smolej 2006: 639) Takrat je bila debata o nacionalni identiteti občutljiva tema, slovenski kulturniki in inteligenca so se namreč zavzemali za posebno mesto v evropski kulturi, nacionalno identiteto pa so iskali v jeziku. Slovenska nacionalna identiteta se je takrat v kulturi uveljavljala zato, ker je bila zaradi unitaristično usmerjene politike in diktatorske Kraljevine Jugoslavije politično onemogočena. Louis Adamič, ki je bil za nastali spor

14 Grahor, Olga, "Smeh v džungli; Avtobiografija ameriškega priseljenca«, Ljubljanski zvon 53/11, 1933: 692-695, 750-752.

15 Prav tam: 693.

16 Župančič, Oton, »Adamič in slovenstvo«, Ljubljanski zvon 52/8, 1932: 513-520. 
$\checkmark$ Ljubljanskem zvonu še najmanj kriv, je bil pomemben sprožilec razprave o kulturnem razvoju slovenske nacionalne identitete, ki je razgrela slovensko literarno in politično javnost (prav tam).

Adamičev obisk v Sloveniji leta 1932 je bil kljub temu dobro sprejet. Takrat se še ni zavedal, da bo s sprejemom delegacije liberalnih piscev iz Ljubljanskega zvona, ki so ga 22. maja 1932 obiskali na njegovem domu v Prapročah, zaprl svoja vrata katoliškim oziroma konservativnim piscem in bralcem, zbranim okoli časopisa Dom in svet. Čeprav je bil omenjeni literarni mesečnik prvi, ki je Adamiča v Sloveniji promoviral in predstavil širši slovenski javnosti, so se zaradi njegovega javnega druženja z liberalci razšli (Adamic 1938: 123).

\section{ODMEVI NA KNJIGO »VRNITEV V RODNI KRAJ«}

Njegova tretja knjiga Vrnitev $v$ rodni kraj je izšla le nekaj mesecev pred atentatom na kralja Aleksandra leta 1934 v francoskem Marseillu. Knjiga je bila napisana kot potopisno, zgodovinsko, sociološko in družbenokritično delo. Revija Literary Digest jo je označila kot najodločilnejšo knjigo v letu 1934, kot »trajen in krasen dodatek k ameriški literaturi«. ${ }^{7} \mathrm{~V}$ Jugoslaviji je bila zaradi kritik vladajočega režima in nestrinjanja z njim prepovedana (Čizmić 1981: 313). Kljub temu so jo v ZDA pohvalili in najmanj 29-krat ponatisnili. ${ }^{18}$ Izšla je tudi v Angliji, Avstraliji, na Novi Zelandiji in v Južni Ameriki. Prevedli so jo v ruščino, francoščino, španščino, danščino in češčino. ${ }^{19}$ Adamič je septembra 1933 v ameriškem marksističnem časopisu New Masses objavil prispevek "What it Means to be a Communist in Yugoslavia«, avgusta istega leta pa v časopisu New Republic članek »White Terror: A Case History«. V njem je opisal brutalna zaslišanja in mučenja, ki jih je jugoslovanski režim izvajal proti komunistom. Na podlagi tega pisanja so pozneje izšli ostri članki, ki so opozarjali na slabe razmere v Jugoslaviji in sprožili javne proteste uglednih ameriških pisateljev proti jugoslovanskim oblastem (Čuljak 1981: 274). Celo New York Times je omenil, da je bila knjiga znanega ameriškega pisatelja Louisa Adamiča v Jugoslaviji prepovedana, ker naj bi vsebovala subverzivno tematiko. ${ }^{20}$ Od takrat so se o Adamiču v slovenskem tisku začeli bolj negativno izražati. Ameriški tisk pa je pisal, kako je Adamičevo pisanje »vabljivo pripovedovanje«, ki ga spremljajo šaljivost, tragedija in ostra kritika režima. ${ }^{21}$

V ljubljanskem orjunaškem tedniku Pohod so zapisali, da je Adamiča »domovina sprejela z navdušenjem «, ko pa je začel o Jugoslaviji pisati »čudne reči« in prikazovati jugoslovanske razmere v negativni luči ter primerjati režim s srednjeveško Španijo iz obdobja inkvizicije, so se mnogi na njegovo pisanje začeli burno odzivati. Režimski

17 SI AS 1557, Louis Adamičeva knjiga - The Native's Returne, 1935: 1.

18 Prav tam.

19 Prav tam, Louis Adamič - kratek opis njegove literarne kariere: 6 .

20 "Book Barred by Belgrade«, New York Times, 17. marec 1934: 13.

21 SI AS 1557, Louis Adamičeva knjiga - The Native's Returne, 1935: 12. 
časopisi, kot je bil Pohod, so slabe razmere v Jugoslaviji branili s primerjavo dogajanj $v$ drugih delih sveta. Navajali so na primer, da nobena država na svetu ni idealna, saj tudi v ZDA prihaja do podobnih primerov policijskega nasilja kot v Jugoslaviji. Nasilne postopke z Jugoslovani so opravičevali s primerjavo z diktatorskimi državami, kakršne so bile Italija, Nemčija in Rusija. Za vse omenjene dežele so poudarili, da imajo daljšo kulturno zgodovino od Jugoslavije, jih pa to ne zaustavi, da v svojih državah ne bi varovali političnega sistema. ${ }^{22}$

Adamičeve opise nasilja in mučenja zapornikov v Jugoslaviji so po eni strani zanikali in označevali kot lažno poročanje, po drugi strani pa so poskrbeli za celo kopico razlogov o pravilnosti takšnega početja. ${ }^{23}$ Razloge, zakaj so oblasti prepovedale knjigo, so navedli v naslednji številki in napisali, da so Adamičeve trditve senzacionalne, pretirane in napol resnične. Navajali so, da so kritični članki, ki so izšli v ameriških časopisih, Adamičevi knjigi odvzemali literarno vrednost. Po mnenju drugih so prav omenjeni kritični članki knjigi dodajali materialno vrednost in se je zato še bolje prodajala. V istem članku citirajo konservativno Ameriško domovino, ki je nekaj dni pred izidom knjige obsodila Adamičevo pisanje, njega pa označila za »komunističnega pisatelja«. ${ }^{24}$ Po mnenju urednika Jamesa Debevca je Adamič Slovence prikazal kot »nekulturne in neumne ljudi« ter kot zaostal narod, ki ga še vedno prežemajo »praznoverja in poganski običaji«. V zaključku članka je omenjeni urednik zapisal, da je Adamiču še večjo pozornost prinesla napoved padca Aleksandrovega režima. Zanimivo, da je urednik Ameriške domovine, torej izseljenskega časnika, ki je izhajal v ZDA, Adamiča preusmeril na ogled newyorških kaznilnic, kjer naj bi se dogajale podobne reči kot v Jugoslaviji. ${ }^{25} \mathrm{~V}$ napredno usmerjeni Enakopravnosti so se nad tem »ciničnim argumentom« opravičevanja nasilja javno zgražali. ${ }^{26}$

Konec leta 1934 je ameriški dopisnik Theodore Andrica obiskal Adamičevo rodno domovino. Svoje vtise je opisal v člankih za dnevnik The Cleveland Press. V njem je poročal, da se v Ljubljani sicer malo govori o izseljenskem pisatelju Adamiču, po njegovem mnenju pa bi se njegova zadnja knjiga v Jugoslaviji dobro prodajala, saj bi javnost gotovo zanimalo, kaj o Sloveniji in Jugoslaviji lahko pove ameriški izseljenec. Andrica je omenil, da v Jugoslaviji obstajajo ilegalne kopije knjige. Vsi, ki so bili vešči angleškega jezika, so se navduševali nad knjigo, seveda z izjemo določenih državnih uradnikov, ki so ostali pokorni režimu. Ameriški dopisnik zaključi, da je le malo ljudi knjigo uspelo prebrati. Na koncu je omenil, da je na poti v Grosuplje, kjer je želel obiskati Adamičevo družino, doživel neprijetnosti; tri postaje pred izstopom so ga legitimirali in kot edinega potnika poslali iz vlaka; do cilja je moral pešačiti še najmanj tri milje oz. eno uro. Tako je poskušal pritrditi pisatelju, da razmere v Jugoslaviji niso

22 »Za resnico«, Pohod, 6. januar 1934: 1.

23 Pravtam.

24 »The Native's Return«, Ameriška domovina, 27. januar 1934: 2.

25 »Ameriška domovina o L. Adamiču«, Pohod, 31. marec 1934: 2.

26 »K dnevnim dogodkom«, Enakopravnost, 23. oktober 1934: 2. 
ravno najboljše. ${ }^{27} \mathrm{~V}$ Prosveti je $v$ tem času izšel komentar na kritike, ki jih je Adamič prejemal v ZDA. Komentar se je glasil:

[...] Ko so zavohali naši clevelandski in pittsburški patrioti, oportunisti in reakcionarji vseh baž, da bo Adamič v tej knjigi poleg drugega pisal tudi resnico o obstoječem jugoslovanskem režimu, so izgubili glavo. Cela zadeva močno diši po zavisti, ker jim je Adamič zrastel preko glave. Človeku nehote sili vprašanje, kaj bi ti ljudje začeli, ko bi bil on na primer aktiven socialist ali celo komunist?

Vendar komentator zaključuje, da Adamiču ni treba skrbeti za ugled, saj ima v ZDA več prijateljev kot sovražnikov. ${ }^{28} \mathrm{~V}$ isti številki Prosvete so knjigi Vrnitev v rodni kraj namenili pozitivno recenzentsko mnenje. Pisali so, da gre za prvo knjigo, ki je v angleščini opisala vse plati življenja v Jugoslaviji. Posebnost knjige je bila v tem, da se avtor ne omejuje zgolj na Slovenijo, ampak opisuje razmere tudi v drugih delih Jugoslavije, kot so Hercegovina, Dalmacija, Srbija, Hrvaška in Črna gora. Opisuje tudi stanje duha v večjih mestih, kot so Beograd, Zagreb, Sarajevo itn. „The Native's Return se čita kakor roman, ki je poln dogodkov in duhovitih primer. ${ }^{29} \mathrm{~V}$ knjigi avtor jasno nakaže, da so njegove simpatije na strani »trpečega in preprostega ljudstva«, torej delavcev in kmetov, ne pa na strani vladajoče elite. ${ }^{30}$ Nasploh je urednik Prosvete Ivan Molek budno spremljal vsako polemiko in reakcijo, ki je zaradi Adamičeve knjige nastala v konservativnih krogih in časopisih, ki so izhajali v ZDA.

V aprilski številki Prosvete so omenjali, da je Adamičeva knjiga že podrla vse prodajne rekorde, v razmeroma kratkem času so prodali več tisoč izvodov. ${ }^{31} \mathrm{~V}$ Adamičevi knjigi, so zapisali, ni slabe besede o narodu ali njegovem sramotenju, saj naroda ne moremo in ne smemo enačiti z obstoječim režimom, ki spada v drugo kategorijo. $\mathrm{V}$ Prosveti Pohodu celo očitajo kritiko Adamičeve knjige, ki jo zagotovo niti videli niso, saj je v Jugoslaviji prepovedana. Torej so navajali mnenja emigrantske kritike, objavljene v Ameriški domovini. V dokaz, da Adamič v knjigi ne sramoti svojega naroda, so navedli Adamičev članek »Who Built America? Profiteers, Professional Patriots or `Vile Immigrants«", ki je izšel v reviji Common Sense in v katerem avtor brani vse slovanske priseljence v ZDA, ki so to deželo pomagali zgraditi. Slovani niso prispevali zgolj »delovne sile«, temveč tudi »umsko silo«, ki sta jo predstavljala Nikola Tesla in Mihajlo Pupin, dva prominentna izumitelja in znanstvenika svojega časa. Adamičevo razmišljanje se ni spremenilo, temveč je ostalo na strani ameriških priseljencev slovanskih korenin, ki so pomagali zgraditi Ameriko in jo ustvariti veliko. Zato je bila Amerika prav toliko njihova domovina kot od vseh drugih. Adamič je o priseljencih govoril kot o »Novoameričanih«. Ni jih prikazoval kot »tujcev«, ki bi se morali asimilirati, am-

27 »Slika iz Slovenije«, Nova doba, 14. november 1934: 2; SI AS 1557, Adamič in Adrica: 77.

28 Česen, Franc, »Glasovi iz naselbine«, Prosveta, 31. januar 1934: 2.

29 »Adamičeva knjiga `The Native's Return«, Prosveta, 31. januar 1934: 4.

30 Prav tam.

31 Zornik, Anton, »Glasovi iz naselbin«, Prosveta, 11. april 1934: 4. 
pak, prav nasprotno, morali bi ohranjati svoje običaje in kulturo ter s tem bogatiti in razširjati ameriško identiteto (Adamič 1951: 82). Adamič je s svojim delovanjem po mnenju Prosvete veliko bolje zastopal interese izseljencev kot kdorkoli drug. ${ }^{32}$

Poleg izdaje člankov in knjig je Adamič v ZDA pripravil še številna predavanja o svojih izkušnjah v Jugoslaviji. Obiskal je vsa pomembna ameriška industrijska mesta, kjer so živeli slovenski izseljenci. Predavanj se je udeleževalo po več sto poslušalcev. Nekaj vtisov so objavili izseljenski časopisi (Adamic 1938: 137), enega med njimi v Prosveti:

Adamič je simpatična osebnost, prikupljive zunanjosti in inteligentnega obraza skratka: naše gore list. Številno avdienco si je na mah osvojil. Kakor Cankar, tudi Adamič ljubi deželo, kjer se je rodil, deželo siromašnega, toda poštenega, ponosnega in vztrajnega ljudstva, deželo naravnih bogastev, romantike, tradicije, zgodovine in ostrih kontrastov. Ne ljubi pa krivične ekonomske in socialne uredbe dežele ter njenih parazitov, ki na račun ljudstva grade palače in se vozijo v limuzinah. Dalje ne ljubi režima, ki s svojim krvavim škornjem tišči narod ob tla in mu odreka vsako pravico svobodnega izražanja. On vidi v Jugoslaviji in Evropi sploh v bližnji bodočnosti mogočni socialni preobrat na levo. ${ }^{33}$

Avtor komentarja Franc Česen je Adamiča politično ocenil kot »levičarsko orientiranega« in »simpatično naklonjenega do Rusije«, ki jo vidi kot zaščitnico majhnih slovanskih narodov. Ameriko pa je dojemal kot »čudovito deželo«, ki jo je najprej treba odkriti in jo, preden bi jo lahko sodili, še preučiti.

Zanimivi so bili poskusi Adamičevih nasprotnikov, ki so ga želeli prikazati kot simpatizerja ekstremnih hrvaških izseljencev. Najprej so ga poskušali povezati z ustaško teroristično organizacijo. Ker jim to ni uspelo, so ga ožigosali kot radikalnega socialista in komunista. V teh poskusih je sodeloval tudi Ivan Hribar, dolgoletni ljubljanski župan, politik, diplomat in takratni jugoslovanski senator. Drugi so ga poskušali tesneje povezati s fašisti, njegovo knjigo naj bi namreč prevedli v italijanski jezik. Po navedbah Prosvete je avtor izdajo italijanskega prevoda zavrnil, italijanski založnik je namreč postavil pogoje, da se v knjigi izpustijo stavki, ki omenjajo fašistično nasilje nad primorskimi Slovenci in Hrvati. Tako je Adamič z zavrnitvijo prevoda pokazal, da mu ne gre toliko za prodajo knjige in osebno slavo kot za resnico in pravico. ${ }^{34} \mathrm{Ada}$ mič je kljub močnim pritiskom in napadom javnih političnih osebnosti, kakršen je bil Hribar, ki je svaril ameriške Slovence pred Adamičevim pisanjem, v svojem pisanju in delovanju ohranil odločnost in neodvisnost. To mu je uspelo zaradi podpore liberalno in socialistično usmerjenih ameriških Slovencev. ${ }^{35}$

32 Podgoričan, Jontez, »Pismo iz Clevelanda«, Prosveta, 23. april 1934: 3.

33 Česen, Franc »O Adamičevem predavanju«, Prosveta, 20. april 1934: 2.

34 »Mimogrede - Neka založba v Milanu«, Prosveta, 8. junij 1934: 2.

35 Hribar, Ivan, »Adamič - senator Hribar, ustaši in kolhozi«, Prosveta, 22. maj 1934: 3. 
Postavlja se vprašanje, kako je lahko Adamičeva knjiga Vrnitev v rodni kraj požela tako velik uspeh in bila že v prvem mesecu po izidu prodana v več kot 55.000 izvodih? Pozneje je doživela še več ponatisov. Med drugo svetovno vojno so jo razdelili med ameriške vojake v Evropi. Prva razlaga je vsekakor povečana ameriška zainteresiranost za balkansko problematiko in Jugoslavijo. Drugo so povzeli v liberalnem časniku Slovenski narod, ki je izhajal v Sloveniji. V njem so navajali, da se je knjiga dobro prodajala predvsem zato, ker jo je največji ameriški knjižni klub Book of the Month Club razglasil za knjigo meseca ter vnaprej zakupil vse izvode, ki so februarja 1934 hitro pošli. ${ }^{36}$ Glavni predstavnik omenjenega kluba, ameriški profesor na yalski univerzi, Henry Seidel Canby, je med tisoč knjigami prav Adamičevo izbral za eno najboljših v ZDA. Pohvalil je tudi dosežek amerikaniziranega avtorja, ki je s svojima talentiranim izrazoslovjem in pripovedovanjem presegel celo najboljše ameriške pisatelje. ${ }^{37}$ Tretja razlaga se skriva v senzacionalnosti Adamičevih člankov in polemik, ki sta jo sprožili smrt kralja Aleksandra in jugoslovanska kriza. Tako lahko v februarski številki New York Timesa beremo, da je knjiga najboljša na tistih mestih, kjer avtor v prvoosebni izpovedi predstavi razmere v svoji rojstni deželi, bralci pa niso soočeni s kopico dolgočasnih dejstev in suhoparno analizo, temveč z zanimivo pripovedjo, ko avtor iz lastnih izkušenj predstavi doživljanje v ameriškem kontekstu razumevanja dogodkov. Knjigo so zato priporočali širokemu krogu bralstva. ${ }^{38}$

Tudi znani Los Angeles Times je Adamiču naklonil pozitivno oceno. Bralcem je knjigo predstavil kot sociološko in antropološko delo, ki ima bistveno širši pomen in ni zgolj navadno potopisno branje. V recenziji je omenjeno, da Jugoslavijo zaradi zaostalosti čaka veliko dela na področju industrializacije. Jugoslavija se bo v prihodnje združila z Rusijo in se razvila ali pa bo propadla v revščini in zaostalosti. ${ }^{39}$ Časnik Daily News je bil v oceni knjige še bolj prijazen in radodaren, saj je knjigo predstavil kot utripajoče srce.

Adamičeva knjiga Vrnitev $v$ rodni kraj je zgodba s srcem. Ima svoj pulz, utrip in je živa. Že res, da je bilo napisanih veliko učenih, zanimivih in slogovno lepih knjig, vendar je malo takih, ki bi bile polne veselja, ki ga je moč začutiti v prvem delu Vrnitve v rodni kraj. Adamič je skozi celo knjigo iskren in ponosen, da se lahko z njim poistovetimo (sic).

Adamič je Jugoslavijo prikazal kot zadnjo absolutistično monarhijo v Evropi. Takšne ocene so bile vsekakor velika spodbuda za ameriške bralce, ki so se odločali za branje političnih in družbenokritičnih tematik. Knjiga je opisovala resnično življenje in tegobe pozabljenega ljudstva v neznanem kraju Jugovzhodne Evrope. Zato je za ameriške bralce postala še bolj zanimiva in atraktivna. ${ }^{40}$

36 »|z življenja ameriških Slovencev«, Slovenski narod, 15. januar 1934: 3.

37 SI AS 1557, Fond Adamič Louis, The Native's Return, januar 1935: 1.

38 »The Glowing Story of a Man's Return to His Home Land«, New York Times, 11. februar 1934: 50.

39 »Adventures in Slovenia« The Los Angeles Times, 18. februar 1934: 36.

40 »Tale of a Slovene Boy who Made Good«, Daily News, 4. februar 1934: 219. 
Adamiču so sprva vsi slovenski izseljenci in časnikarji $v$ »stari domovini« peli hvalo, nekateri so ga celo kovali v nebo kot »vzhajajočo zvezdo« in neodvisnega ter talentiranega pisatelja, ki s svojima smehom in humorjem osvaja ameriško in jugoslovansko publiko. ${ }^{41} \mathrm{Ko}$ pa je Adamič po povratku iz Jugoslavije začel pisati neprijetne zgodbe o »stari domovini«, so se pričakovanja nekaterih izseljencev močno ohladila. Adamič je svoje poglede opisoval, kot jih je doživljal in občutil na lastni koži. Simpatizerji beograjskega režima, ki jih je bilo nekaj tudi v Ameriki, so se začeli od njega oddaljevati, predvsem je bilo to očitno pri srbski izseljenski skupnosti, zbrani okoli glasila Srbobran. ${ }^{42}$

Treba je omeniti, da sta Adamiča jugoslovanski javnosti predstavili prav srbska in hrvaška literarna srenja (Hedžiselimović 1981: 283). Sledili so katoliško usmerjeni slovenski izseljenci, ki so svoja razmišljanja objavljali v Ameriški domovini, Amerikanskem Slovencu in drugih podobnih glasilih, v Sloveniji pa v Domu in svetu. Ko pa so se v drugi polovici leta 1933 obrnili proti Adamiču, so o njem zapisali: »V svoji rojstni vasi Blato je nagrabil blata, s katerim je svoj lastni narod pred tujci oblatil.« Zamerili so mu njegovo iskreno pisanje o Kraljevini Jugoslaviji in nasploh njegove opazke o slovenskih običajih. Nekateri nasprotniki so menili, da bi bilo bolje, če bi se Adamič preimenoval v »Adamsa«, saj naj bi se s svojim priimkom še naprej predstavljal za Slovenca. Drugi so se obregnili ob njegovo ime »Louis«, ki ni bila prava izpeljanka za slovenskega Lojzeta. Louis je bil namreč Ludvik, vendar se je bralec Prosvete vprašal, če je to sploh pomembna podrobnost. ${ }^{43}$ Seveda so bile za katoliško usmerjene Slovence primerjave s poganstvom izredno žaljive. Adamiča so začeli poučevati, naj raje $v$ roke vzame kakšno knjigo, $v$ kateri si bo razjasnil osnove katekizma in odkril razliko med verovanjem in ljudskimi običaji. ${ }^{44}$ Neko drugo pismo bralcev zelo jasno prikaže jezo ameriškega Slovenca, ki o Adamiču zapiše naslednje: »Jaz nikakor ne morem razumeti, zakaj je rojak tako zapisal? Slovenci pogani! Naš narod, ki je najbolj veren narod v Evropi! ... Pisati tako se pravi norčevati iz naroda.« Potem nadaljuje, da Adamič verjetno dobro ve, da je njegovo pisanje o Slovencih kot narodu poganov neresnično. Namiguje namreč, da je tako pisal zaradi denarja, kar po njegovem zmanjšuje literarno vrednost knjige. Pravi umetniki in kulturniki ne delajo za denar, je še dodal. ${ }^{45}$

Adamičev odgovor na pisma in kritike, ki so se pojavljale pred izidom knjige Vrnitev $v$ rodni kraj, so objavili Prosveta in drugi napredni časniki. Na najbolj kritičen članek, ki ga je v Amerikanskem Slovencu podpisal pater Hugo, je Adamič odgovoril:

41 »Louis Adamiča ıSmrt na Kranjskem«, Amerikanski Slovenec, 28. november 1933: 2.

42 »Adamičevo pismo«, Prosveta, 4. oktober 1933: 3.

43 Podgoričan, Tone, »Pismo iz Clevelanda«, Prosveta, 2. maj 1933: 2.

44 »Louis Adamiča 'Smrt na Kranjskem«, Amerikanski Slovenec, 28. november 1933: 2.

45 »Rojak podaja svoje mnenje o Adamiču svojemu prijatelju«, Amerikanski Slovenec, 7. november 1933: 2 . 
Kaj naj odgovorim? Članek je odmev iz srednjega veka. Ali naj argumentiram s srednjim vekom? Naj polemiziram s srednjeveško institucijo, katera v aktualni dnevni praksi podpira socialno-ekonomski sistem, ki je odgovoren za oceane človeške mizerije, ta mizerija pa je obratno vir moči te institucije? Ali naj argumentiram s policajem kapitalističnega sistema? Ta argument je bil že davno zaključen po boljših pisateljih kot sem jaz - po Voltairu, Paineju, Ingersolu in drugih. ${ }^{46}$

Naprej je Adamič razlagal, da svojih člankov ne piše po diktatu založnikov, ampak po svoji vesti. Pojasnil je tudi, da so imeli njegovi članki pri Američanih pozitiven odziv. Omenja, da se mu je s pismi oglasilo najmanj 700 Američanov, ki so se začeli zanimati za Slovenijo in jo prepoznali kot lep kraj. ${ }^{47}$

Odnos kritičnega dela izseljenske populacije do Adamiča se je še poslabšal po umoru jugoslovanskega kralja Aleksandra 9. oktobra 1934. Takrat so se do Adamiča močno razvneli strasti, sovraštvo in nevoščljivost. Poskušali so omajati njegov ugled, ki si ga je ustvaril s svojim trdim delom in pisanjem. Napadi so postali osebni in nizkotni. ${ }^{48}$ Treba je poudariti, da so Adamiču ob strani stali predvsem njegovi socialistično in liberalno usmerjeni ameriški Slovenci, ki so se v Prosveti, Proletarcu in Enakopravnosti pogosto oglašali njemu v bran. Prav oni so Adamiča označili za nekakšnega preroka, ki je napovedal atentat na kralja. Če bi kralj upošteval Adamičeve nasvete, naj se Jugoslavija čim prej demokratizira in odpravi nepotrebno nasilno diktaturo, bi kralj atentat lahko celo preprečil. ${ }^{49}$ Newyorški časnik World-Telegram ga je proglasil za preroškega poročevalca, ki ga je treba jemati resno. ${ }^{50}$ Pomembno je še dodati, da je Adamič videl rešitev jugoslovanske krize v njeni federalizaciji. Tako je, še preden se je ideja uresničila, Adamič uvidel pomen koncepta, ki je pozneje omogočil konstituiranje republik, samoodločbo narodov in jugoslovansko federacijo. S tem je Adamič utrdil svoj ugled političnega in zgodovinskega poznavalca Jugoslavije in širšega Balkana. Tukaj je treba poudariti, da so se ameriški Slovenci že med prvo svetovno vojno zavzemali za federativno Jugoslavijo, vendar takrat še niso imeli Adamiča, da bi prenesel njihove ideje širši ameriški javnosti in bi jim ta prisluhnila. Adamičevi članki, ki so izhajali v raznih časopisih po ZDA, so dosegali najmanj 40 milijonov Američanov ${ }^{51}$ (Klemenčič 2001: 54).

46 Adamič, Louis, »Adamičev odgovor p. Hugonu«, Prosveta, 6. december 1933: 4.

47 »Adamič in ameriška javnost«, Enakopravnost, 20. december 1934: 4.

48 "Lojzetu Adamiču«, Glas naroda, 16. oktober 1934: 2.

49 »Adamič je še lani napovedal umor Aleksandra", Prosveta, 11. oktober 1934: 1.

50 »Yugoslav Writer Predicted Alexander's Assassination«, New York World Telegram, 9. oktober 1934: 1.

51 »Adamičev članek o Jugoslaviji«, Prosveta, 22. oktober 1934: 2; „What is Next in Jugoslavia?«, Nation, 24. oktober 1934: 470-471; SI AS 1557, Louis Adamičeva knjiga - The Native's Returne, 1935: 6 . 
Zaradi odmeva, ki ga je sprožila polemika o mučenju političnih zapornikov, zlasti komunistov v Jugoslaviji, je Adamič pripravil novo majhno knjižico z naslovom Boj; 52 knjižica je nadaljevanje knjige Vrnitev $v$ rodni kraj. Knjižica, ki je izšla poleti 1934, je bila v Jugoslaviji takoj po izidu prepovedana. ${ }^{53}$ Tovrstni članki, knjige in pozneje odkrita obsodba jugoslovanskega režima so Adamiča spravljali v neprijeten položaj, in čeprav so ga mnogi izseljenski in domači časnikarji dnevno kritizirali, blatili in napadali, njegovega imena niso mogli okrniti. Ostal je edini Američan slovenskega rodu, ki mu je v tem času uspelo objavljati članke in mnenja v uglednih ameriških časnikih. ${ }^{54}$ Adamič je imel po besedah Prosvetinih bralcev bistveno več prijateljev kot sovražnikov, čeprav so ga slednji razglašali za izdajalca in odpadnika svojega rodu. Končno sodbo naj bi dala zgodovina in ne sodobniki, ki pišejo na podlagi čustev in političnih prepričanj. ${ }^{55}$ Nasprotniki so Adamiča poskušali na vse načine zvabiti, da bi se odzval na nizkotne napade, ampak Adamič se je modro zadrževal in redko javljal. V bistvu se je odzval samo na pisanje Srbobrana in patra Hugona. (Orahovac 1981: 268-269)

Adamiča so prve tri knjige, ki jih je izdal med letoma 1931 in 1934, preusmerile na druga področja. Postal je ameriški izvedenec za priseljenske teme. Ameriška vladna agencija FLIS (Foreign Language Information Service), ki ga je prva prepoznala kot poznavalca na tem področju, ga je izvolila v svoj izvršni odbor. Že prej se je na potovanju po Jugoslaviji zavedel, da je vprašanje nacionalne identitete enako pomembno kot delavske pravice. Ugotovil je, da je za razumevanje problematike ameriške družbe, kjer živi veliko priseljencev iz raznih dežel, potrebna poglobljena analiza. Tako je nastala njegova naslednja knjiga lz mnogih dežel, prva iz zbirke Narod narodov, za katero je prejel prestižno Anisfieldovo nagrado in častni doktorat iz literarnih ved. Pri iskanju odgovorov na pereča vprašanja ameriške družbe in politične usode svoje rodne Slovenije oziroma Jugoslavije je ves čas ostal neodvisen. (Adamic 1938: 187-194; Žitnik 1995a: 13-16)

\section{ZAKLJUČEK}

Kot je razvidno iz zgoraj zapisanega, je Adamičevo delo poželo veliko odmevov na obeh straneh oceana. Že od začetka njegovega delovanja so ga vsi kritiki odobravali, pozneje, po izidu njegove knjige Vrnitev v rodni kraj, v kateri je Adamič kritiziral kralja in beograjski režim, so ga tudi slovenski kritiki sprva samo zavračali, pozneje pa o njem, razen redkih izjem, sploh niso več poročali. V ZDA je večina glavnega

52 Temeljni tekst je za omenjeno knjižico pripravil Edvard Kardelj. Vendar izvirnika nikoli niso našli. Zato je še vedno vprašanje, koliko teksta je dejansko Kardeljevega in koliko je Adamič dodajal svojega?

53 »Adamičeva knjiga prepovedana«, Slovenec, 17. julij 1934: 2.

54 »Alexander the Not-So-Great«, The Tribune, 19. december 1933: 4.

55 Jontez, Ivan, »Pismo iz Clevelanda«, Prosveta 24. oktober 1934: 3. 
tiska pozitivno sprejemala vsa Adamičeva dela. Med slovenskim etničnim časopisjem v ZDA so ga pozitivno sprejemali politična levica in liberalci, medtem ko ga je konservativno časopisje zaradi njegovih kritik religije, kralja in Jugoslavije še naprej kritiziralo in zavračalo.

\section{LITERATURA}

Adamic, Louis (1931) Dynemite: The Story of Class Violence in America. New York: Viking Press.

Adamic, Louis (1938). My America 1928-1938. New York, London: Harper \& Brothers.

Adamič, Louis (1951). Iz dveh domovin. Maribor: Založba Obzorja.

Adamič, Louis (1983). Dinamit. Ljubljana: Založba Borec.

Christian, Henry (1981b). Izbrana pisma Louisa Adamiča. Ljubljana: Cankarjeva založba. Christian, Henry (1971a). A Checklist. Kent: State University Press.

Čizmić, Ivan (1981). The Native's Return: Its Impact. Louis Adamič simpozij. Univerza Edvarda Kardelja v Ljubljani, 313-321.

Čuljak, Milan (1981). Povratak domoroca - Počeci Adamičevog opredeljenja za novu Jugoslaviju. Louis Adamič simpozij. Univerza Edvarda Kardelja v Ljubljani, 271-281.

Hadžiselimović, Omar (1981). Odjek Adamičevih djela u kritici na srpskohrvatskom jeziku izmedju dva rata. Louis Adamič simpozij. Univerza Edvarda Kardelja v Ljubljani, 281-189.

Klemenčič, Matjaž (1981). Politično delo Louisa Adamiča. Teorija in praksa 18/9, $1054-$ 1068.

Klemenčič, Matjaž (2001). Odnos slovenskih izseljencev do stare domovine. Slovensko izseljenstvo. Zbornik. Ljubljana: Združenje slovenske izseljenske matice, 53-63.

Klemenčič, Matjaž (2011). Življenje in delo ameriškega politika Franka Lauscheta s posebnim ozirom na slovenske zadeve. SHS - časopis za humanistične in družboslovne študije 2-3, 735-763.

Orahovac, Sait (1981). Kako je nastala Adamičeva knjiga Povratak domoroca. Louis Adamič simpozij. Univerza Edvarda Kardelja v Ljubljani, 265-271.

Petrič, Jerneja (1981). Svetovi Louisa Adamiča. Ljubljana: Cankarjeva založba.

Shiffman, Dan (2005). Korenine multikulturalizma - Delo Louisa Adamiča. Ljubljana: ZRC.

Smolej, Tone (2006). Poglavje iz zgodovine Ljubljanskega zvona. Slavistična revija $54 / 4,639$.

Žitnik, Janja (1995a). Pogovori o Louisu Adamiču. Ljubljana: Prešernova družba.

Žitnik, Janja (1995b). Orel in korenine med 'brušenjem in cenzuro'. Ljubljana: ZRC.

Žitnik, Janja (2002). Louis Adamic and Slovene Identity. Slovene Studies 19/1-2, 121-130. 


\section{ČASOPISNI VIRI}

Amerikanski Slovenec, 1933.

Ameriška domovina, 1934.

Daily News, 1934.

Dom in svet, 1931, 1932, 1933.

Enakopravnost, 1934.

Glas naroda, 1934.

Ilustracija, 1931.

Jutro, 1931.

Ljubljanski zvon, 1932, 1933.

Mariborski Večernik Jutra, 1931.

New York Times, 1931, 1934.

New York World Telegram, 1934.

Nova doba, 1934.

Pohod, 1934.

Prosveta, 1931, 1933, 1934.

Slovenec, 1932.

Slovenski narod, 1934.

The Los Angeles Times, 1934.

\section{ARHIVSKI VIRI}

Arhiv Slovenije, SI AS 1557, Fond Louis Adamič. 


\section{SUMMARY}

\section{REACTIONS TO ADAMIC'S WORK IN THE AMERICAN AND SLOVENIAN PRESS BETWEEN 1931 AND 1934 Milan MRĐENOVIĆ}

The author describes the analyses of Louis Adamic's writings in the Slovenian press and in the Slovenian immigrant press in the USA in the period from 1931 to 1934. Adamic initially intended to write fiction, but upon publishing his first book on the workers' movement, trade unions and the general developments of society, entitled Dynamite, he gained enough recognition to gradually dedicate himself to other areas of writing. He was awarded a Guggenheim Fellowship for his autobiography Laughing in the Jungle, which allowed him to travel to Yugoslavia in 1932. This journey provided him with precious material for his new book The Native's Return, which brought him significant recognition in the USA. The article deals with positive and negative reactions to Adamic's three major books at the time of their publication between 1931 and 1934. The author explores the developments of the topics found in the respective publications, dealing with immigrant, political and social issues. He also touches upon Adamic's response to King Alexander's assassination in 1934. Adamic's The Native's Return cemented his reputation as an expert on the politics and immigrant issues in the Balkans, which he was able to put to good use during his later years of activism in this field. 